
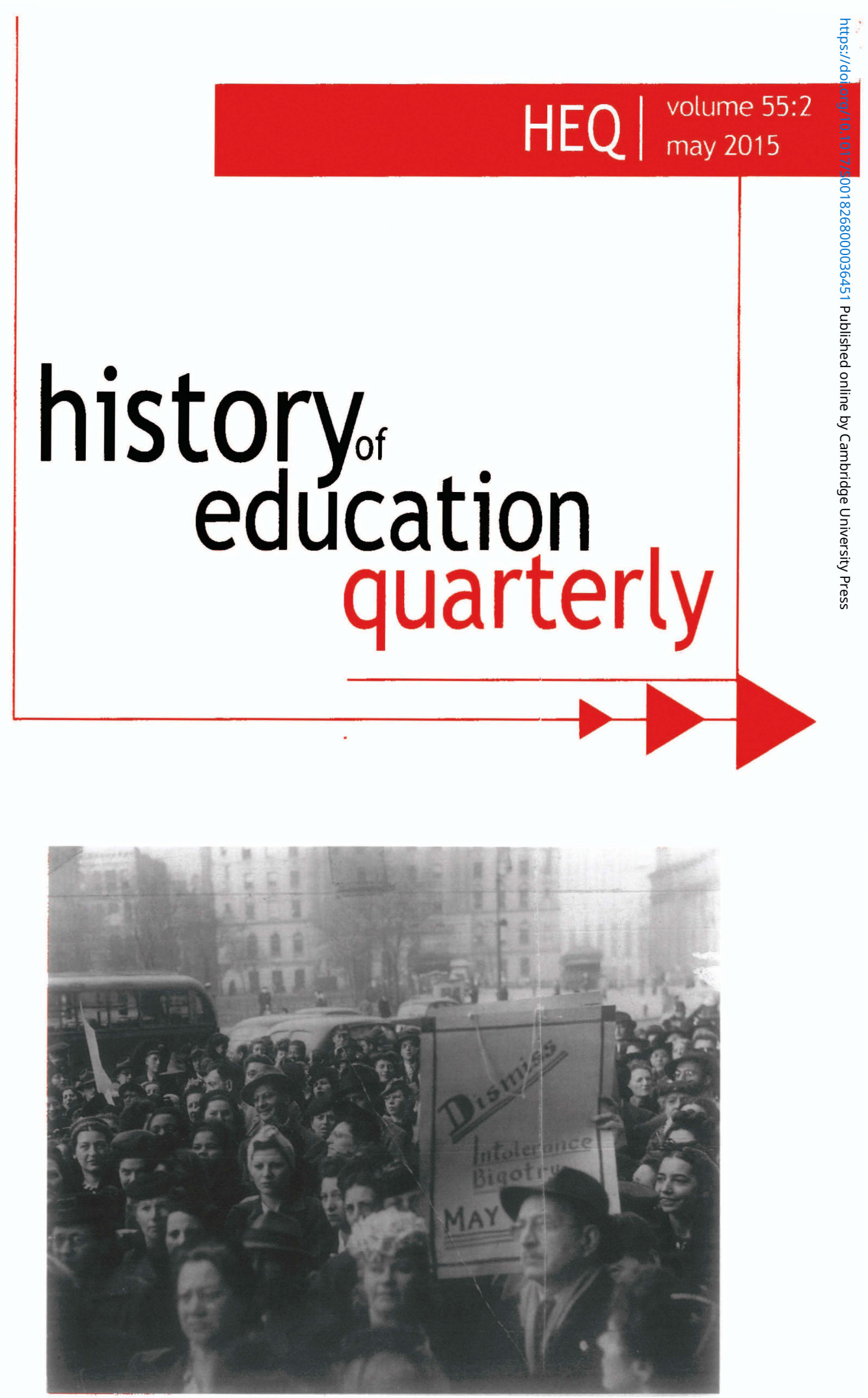
Article Submissions: Manuscripts must be submitted electronically to the History of Education Quarterly manuscript submission site, http://ojs.ed.uiuc.edu/index.php/heq/index. Questions regarding submissions can be directed to the editorial staff at heq@ed.uiuc.edu. See the last page of this issue or our website http://www.wiley.com/bw/journal.asp? ref $=0018-2680 \&$ site $=1$ for guidelines on submission. The editor will only consider articles that have been submitted exclusively to the History of Education Quarterly. It is the responsibility of the manuscript author(s) to ensure that all submissions are in accordance with our plagiarismpolicy, which can be found at: http://authorservices.wiley.com/bauthor/ publicationethics.asp\#_Toc149460090

Book Reviews: Assignments of reviews are made from a file of potential reviewers. To have your name added to that file, send curriculum vitae to the book review editor. Requests to review particular books cannot be honored.

HISTORY OF EDUCATION QUARTERLY (Print ISSN: 0018-2680 Online ISSN: 1748-5959) is published quarterly on behalf of the History of Education Society in conjunction with the College of Education, the University of Illinois at Urbana-Champaign, 351 Education Building, MC-708, 1310 South Sixth St., Champaign, IL61820 by Wiley Subscription Services, Inc., a Wiley Company, 111 River St., Hoboken, NJ 07030-5774.

Mailing: Periodical Postage Paid at Hoboken, NJ and additional offices.

Postmaster: Send all address changes to HISTORY OF EDUCATION QUARTERLY, John Wiley \& Sons Inc., C/O The Sheridan Press, PO Box 465, Hanover, PA 17331.

Publisher

History of Education Quarterly is published by Wiley Periodicals, Inc., Commerce Place, 350 Main Street, Malden, MA 02148; Telephone: 781388 8200; Fax: 7813888210

Journal Customer Services: For ordering information, claims and any inquiry concerning your journal subscription please go to www.wileycustomerhelp.com/ask or contact your nearest office.

Americas: Email: cs-journals@wiley.com; Tel: +17813888598 or +18008356770 (toll free in the USA \& Canada).

Europe, Middle East and Africa: Email: cs-journals@wiley.com; Tel: +44 (0) 1865778315

Asia Pacific: Email: cs-journals@wiley.com; Tel: +65 65118000

Japan: For Japanese speaking support, Email: cs-japan@wiley.com; Tel: +65 65118010 or Tel (toll-free): 00531650480.

Visit our Online Customer Help available in 7 languages at www.wileycustomerhelp.com

Production Editor: Aldreen Cruz (email: HOEQ@wiley.com)

Information for Subscribers

History of Education Quarterly is published in 4 issues per year. Subscription prices for 2015 are: Institutional Print \& Online Rate: US\$210 (the Americas), US\$263 (and Rest of World), $€ 173$ (Europe), £136 (UK). Prices are exclusive of tax. Asia-Pacific GST, Canadian GST/HST and European VAT will be applied at the appropriate rates. For more information on current tax rates, please go to www.wileyonlinelibrary.com/tax-vat. The price includes online access to the current and all online back files to January 1, 2011, where available. For other pricing options, including access information and terms and conditions, please visit www.wileyonlinelibrary.com/access.

Delivery Terms and Legal Title

Where the subscription price includes print issues and delivery is to the recipient's address, delivery terms are Delivered at Place (DAP); the recipient is responsible for paying any import duty or taxes. Title to all issues transfers FOB our shipping point, freight prepaid. We will endeavour to fulfil claims for missing or damaged copies within six months of publication, within our reasonable discretion and subject to availability.

Back Issues: Single issues from current and recent volumes are available at the current single issue price from cs-journals@ wiley.com. Earlier issues may be obtained from Periodicals Service Company, 351 Fairview Avenue - Ste 300, Hudson, NY 12534, USA. Tel: +1 518 822-9300, Fax: +1 518 822-9305, Email: psc@periodicals.com.

\section{Copyright and Copying}

Copyright (C) 2015 History of Education Society. All rights reserved. No part of this publication may be reproduced, stored or transmitted in any form or by any means without the prior permission in writing from the copyright holder. Authorization to copy items for internal and personal use is granted by the copyright holder for libraries and other users registered with their local Reproduction Rights Organisation (RRO), e.g. Copyright Clearance Center (CCC), 222 Rosewood Drive, Danvers, MA 01923, USA (www.copyright.com), provided the appropriate fee is paid directly to the RRO. This consent does not extend to other kinds of copying such as copying for general distribution, for advertising or promotional purposes, for creating new collective works or for resale. Special requests should be addressed to: permissions@wiley.com

Advertising: Fơ advertising inquiries, please email Kristin McCarthy (email: kmccarthy@wiley.com)

Disclaimer

The Publisher, History of Education Society, and Editors cannot be held responsible for errors or any consequences arising from the use of information contained in this journal; the views and opinions expressed do not necessarily reflect those of the Publisher, History of Education Society, and Editors, neither does the publication of advertisements constitute any endorsement by the Publisher, History of Education Society, and Editors of the products advertised.

Access to this journal is available free online within institutions in the developing world through the AGORA initiative with the FAO, the HINARI initiative with the WHO, OARE initiative with UNEP, and the ARDI initiative with WIPO. For informatión, visit www.aginternetwork.org, www.who.int/hinari/en/, www.oarescience.org, www.wipo.org/int/ardi/edn

This journal is available online at Wiley Online Library. Visit www.wileyonlinelibrary.com to search the articles and register for table of contents email alerts.

Wiley's Corporate Citizenship initiative seeks to address the environmental, social, economic, and ethical challenges faced in our business and which are important to our diverse stakeholder groups. Since launching the initiative, we have focused on sharing our content with those in need, enhancing community philanthropy, reducing our carbon impact, creating global guidelines and best practices for paper use, establishing a vendor code of ethics, and engaging our colleagues and other stakeholders in our efforts.

Follow our progress at www.wiley.com/go/citizenship

View this journal online at wileyonlinelibrary.com/journal/hoeq

For submission instructions, subscription and all other information visit: www.wileyonlinelibrary.com.

ISSN 0018-2680 (Print)

ISSN 1748-5959 (Online)

HISTORY OF EDUCATION QUARTERLY accepts articles for Open Access publication.

Please visit http://olabout.wiley.com/WileyCDA/Section/id-406241.html for further information about OnlineOpen

Printed in the USA by The Sheridan Group 
History of Education Quarterly.

University of Illinois at Urbana-Champaign

College of Education

Education Policy, Organization and Leadership

1310 S. Sixth Street, MC-708

Champaign, IL 61820

Senior Editors

James D. Anderson, University of Illinois at Urbana-Champaign

Nancy Beadie (2015), University of Washington

Yoon K. Pak,

University of Illinois at Urbana-Champaign

Joy Williamson-Lott (2015),

University of Wasbington

\section{Co-Editors}

Christopher M. Span, University of Illinois at Urbana-Champaign

Book Review Editors

Timothy R. Cain, University of Georgia

Isaac Gottesman (2015), Iowa State University

David W. Adams, Cleveland State University

Kate Rousmaniere, Miami University

Paul W. Mathewson

Kathryn Nicholas (2015)
Associate Editors

Eileen Tamura, University of Hawai'i at Manoa Wayne Urban, University of Alabama

Editorial Assistants

Copy-Editor and Book Review Editorial Assistant

Suzanne M. Reilly, University of Illinois at Urbana-Cbampaign

\section{Editorial Board}

Roland Coloma, Miami University

Dionne Danns, Indiana University

Ansley T. Erickson, Teachers College Columbia

University

Matthew Gilbert, University of Illinois -

Urbana-Champaign

Jon Hale, College of Charleston

Mary Hoffschwelle, Middle Tennessee State University
Judith Kafka, Baruch College, City University of New York

Anne Meis Knupfer, Purdue University

David Labaree, Stanford University

Victoria-Maria McDonald, University of Maryland

Tracy L. Steffes, Brown University

Sevan Terzian, University of Florida

Paul Theobald, Buena Vista University

The History of Education Society is an international scholarly society. Its purposes are to encourage and facilitate research in the history of education; to promote and improve the teaching of history of education; to encourage cooperation among specialists in history of education; and to promote an appreciation of the value of historical perspective in the making of educational policy. The Society is affiliated with the International Standing Conference for the History of Education, and members of the Society are automatically members of the Standing Conference.

\section{Past-President \\ James W. Fraser \\ New York University}

\section{President}

Christine Ogren,

University of Iowa

\author{
Vice President \\ Adam Nelson, \\ University of Wisconsin
}

\section{Secretary-Treasurer \\ Ralph Kidder} Marymount University

\section{Margaret Nash, University of California, Riverside Directors $\quad$ Sevan Terzian, University of Florida}

INDIVIDUAL MEMBERSHIP: Membership is open to all persons interested in the study of the history of education. Membership provides for subscription to the History of Education Quarterly; subscription to The Network, a newsletter published jointly with Division F of the American Educational Research Association; and receipt of the program of the annual meeting of the Society. Members of the Society are automatically members of the International Standing Conference for the History of Education. Membership offers subscription to publications on a calendar-year basis only. Dues are $\$ 25$ for students, $\$ 50$ for others. Non-U.S. members should add \$7 to cover additional postage for surface mail; \$20 for airmail. To become a member, send a check for the appropriate amount in U.S. dollars only to Journal Customer Services, John Wiley \& Sons, 350 Main Street, Malden, MA 02148, USA, or to pay by credit card visit http://ordering.onlinelibrary.wiley.com/Membership.asp?ref =1748-5959\&site $=1$

Make checks payable to John Wiley \& Sons. Indicate preferred mailing address and the calendar year in which your subscription should begin. 


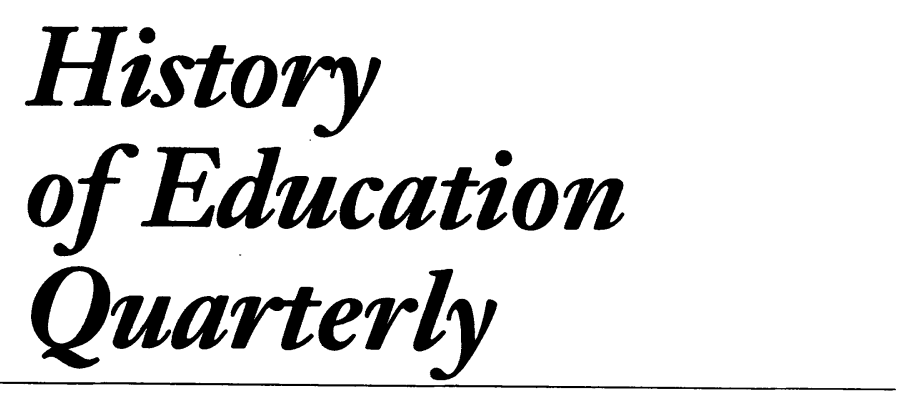

Volume 55 • Number 2 • May 2015

\section{Contents}

\section{Articles}

133 Trouble in Suburbia: Localism, Schools and Conflict in

Postwar Johnson County, Kansas

Fobn L. Rury

164 "Democratizing" Fundraising at Elite Universities:

The Discursive Legitimation of Mass Giving at

Yale and Harvard, 1890-1920

190 "The Penny Lunch Has Spread Faster than the Measles":

Children's Health and the Debate over School Lunches in

New York City, 1908-1930

218 "A War of Ideas": The Rise of Conservative Teachers in Wartime New York City, 1938-1946

Zö̈ Burkbolder

\section{Book Review}

244 Cohen-Cole, The Open Mind: Cold War Politics and the Sciences of Human Nature

Ethan Scbrum

\section{Essay Review}

$248 \quad$ Regional Pride and Prejudice in Programs and Policies fobn R. Thelin 


\section{Book Reviews}

254 Meckel, Classrooms and Clinics: Urban Schools and the Protection and Promotion of Child Health, 1870-1930

$258 \quad$ Neuman, Indian Play: Indigenous Identities at Bacone College Suzanne Reilly

262 Straus, Death of a Suburban Dream: Race and Schools in Compton, California

Sherman Dorn

266 Sumner, Collegiate Republic: Cultivating an Ideal Society in Early America

Catberine Kerrison

270 Thelin, Essential Documents in the History of American Higher Education

Jana Nidiffer

For complete information on the various History of Education Society awards and deadlines, please refer to the society's official website at http://www.historyofeducation.org/.

PHOTO CREDIT: Sign: Dismiss Intolerance and Bigotry, May Quinn, The Mildred Grossman Photo Archive. Accessed: http:// dreamersandfighters.com/multi/archive-pix.aspx 